\title{
Medical History Indicator
}

National Cancer Institute

\section{Source}

National Cancer Institute. Medical History Indicator. NCI Thesaurus. Code C95341.

An indication as to whether there is a relationship to an individual's medical history. 